\title{
Indonesian Undergraduate EFL Students' Perceptions Toward Flipped Classroom
}

\author{
Amanda Vira Maharani, Hamamah, Ika Nurhayani \\ Master's Program in Linguistics, Faculty of Cultural Studies, \\ Universitas Brawijaya
}

\section{Edcomtech}

Jurnal Kajian

Teknologi Pendidikan

Volume 5, No 1, April 2020

$1-10$

Submitted 07-11-2019

Accepted 17-12-2019

Corresponding Author

Amanda Vira Maharani amandaviram@gmail.com

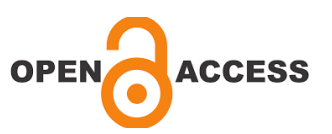

\begin{abstract}
Abstrak
Tujuan dari penelitian ini adalah untuk menemukan persepsi mahasiswa EFL Indonesia terhadap penerapan flipped classroom. Penelitian ini menggunakan desain survey dan data dikumpulkan melalui kuesioner dan disebarkan kepada 30 siswa yang mengalami implementasi flipped classroom. Kuesioner terdiri dari dua aspek, yaitu aspek kebermaknaan dan kompetensi. Hasil kuesioner dihitung secara statistik. Data pada aspek kebermaknaan mengungkapkan bahwa sebagian besar siswa memiliki persepsi positif terhadap pelaksanaan flipped classroom. Di sisi lain, dalam aspek kompetensi, siswa merasa bahwa flipped classroom bermanfaat untuk kompetensi menulis mereka. Namun, untuk kegiatan pra-kelas, seperti menonton video dan membaca materi daring, siswa memiliki berbagai persepsi di dalamnya. Mereka menyukai ide untuk meononton video pengajaran dan materi daring tambahan untuk mempersiapkan mereka sebelum kelas, tetapi mereka tidak benar-benar melihat arti pada pelaksanaan kegiatan pra-kelas tersebut.
\end{abstract}

Kata kunci: flipped classroom, persepsi mahasiswa, mahasiswa EFL

\begin{abstract}
The aim of this study was to find Indonesian undergraduate EFL students' perceptions towards the implementation of flipped classroom. This study implemented survey research design and perceptions were found out through questionnaire and the questionnaires were spread to 30 students who experienced the implementation of flipped classroom. The questionnaire consisted of two aspects, namely meaningful and competence aspects. The results of questionnaire of perceptions were statistically calculated. The data on meaningful aspect revealed that mostly the students had positive perceptions toward the implementation of flipped classroom. On the other hand, in competence aspect, the students perceived that flipped classroom was beneficial for their writing competence. However, for the pre-class activities, such as viewing video and reading e-materials, the students had varied perceptions on it. They actually like the idea to have an additional video-lecture and e-material to prepare them before the class, but they did not really see the meaning by doing that pre-class activities.
\end{abstract}

Keywords: flipped classroom, students' perceptions, undergraduate EFL students 


\section{INTRODUCTION}

We live in a digital era where a lot of devices, such as computer, laptop, and smartphone, take part in our life and somehow we are used to it. This is one of the advantages that can be utilized and applied in educational method. As the curriculum is growing year by year, device can take part as a tool to do an interactive activity, namely online tutorial and quiz (Arnold-Garza, 2014). This needs an instructional learning method that combines the technology and face-toface learning which allow students to be the centered of the learning process. Flipped classroom is a combination of e-learning and face-to-face instructional principles by integrating activities, resources, support and assessment (Gagnon, Mendoza, CarlstedtDuke, 2017). Reidsema, Kavanagh, \& Hadgraft (2017) stated that flipped classroom is to engage the student by doing pre-class activity via online learning as a preliminary learning that is prepared by the instructor then aligned with in-class activity that is guide by the instructors.

There was a study by Afrilyasanti, Cahyono, \& Astuti (2016) investigated the effect of flipped classroom on writing ability of high school students in Indonesia. The results showed that there was a significant difference between flipped and traditional classroom and also between before and after flipped classroom was implemented. The suggestion in implementing flipped classroom was the teacher to concern more not only on material but also how to spend the in-class activity. Moreover, to have another perspective on flipped classroom implementation in Indonesia, similar study with different group of learners is needed.

Another study by Ahmed (2016) explored the effect of flipping classroom on Saudi Arabian undergraduate EFL learners. The flipped classroom was implemented in writing class. As pre-class activity, the teacher provided video and sound recorded PowerPoint uploaded on online class developed by the university itself. The implementation applied about three months in every week meeting. The results showed that the outcome of experimental group was significantly higher than the control group.
Not only in EFL environment, has flipped classroom also successfully enhanced the students' engagement in another field. A study by Ishak, Kurniawan, \& Zainuddin (2019) did a flipped classroom method in management course. The result showed that flipped classroom left a good impression toward the students.

After the implementation of the flipped classroom, it is great to evaluate or to find out whether this model is actually giving a good effect or not by looking at the students' perceptions. A study by Yujing (2015) looked at the at students' perceptions towards flipped classroom in English writing courses in China, the results showed that flipped classroom were able to develop students' attention and interest in learning.

The previous studies by Ahmed (2016), Afrilyasanti, et al. (2016), Ishak, et al. (2019), and Yujing (2016) are good examples how flipped classroom was implemented. Nevertheless, considering this is a new learning model in Indonesia, it is necessary to not only implementing the model but also finding out about students' point of view towards the flipped classroom model. Thereupon, this present study is to fulfill the gap on implementation flipped classroom at university level on the writing ability in Indonesia, as in tertiary level the students need more interactive and practical to everyday and work environment, as well as finding out their perspectives on flipped classroom after taught by this learning model.

\section{Flipped Classroom}

Flipped classroom is not only flipping what has been done in class, now is done at home, but beyond of that. Bishop and Verleger (2013) defines flipped classroom as a technological based individual activity outside classroom and a collaborative learning with peers and instructor in class. Moreover, flipped classroom is not only re-structured of classroom activities, instead it is a curriculum development. Flipped classroom is combining technologies, face-to-face learning, and active learning in which the student is the center of its process. 
Flipped classroom method includes two parts: (1) online based individual learning activities (web-based video lecture and following assignment) as pre-class activity outside classroom and (2) interactive studentcentered learning activities at classroom as in-class activity (Bishop \& Verleger, 2013). In flipped classroom, the students must be aware what to be accomplished prior, whilst, and after the class. In prior activities or outside the class activities, the instructor needs to introduce the objective. Meanwhile in traditional classroom, the objectives can be introduced in any time; before, while, or after the activities. It can be concluded that flipped classroom can be successful if a clear, consistent and constant communication intertwined between instructor and students (Hsieh, 2017).

\section{Benefits and Challenged on Implementing Flipped Classroom}

Flipped classroom may look simple, yet if it is not well-care it will lead into bad teaching. Flipped classroom needs a lot of care because instructor need to input the video and quiz on the online platform and prepare the activities on classroom. The instructor need to do reflection every after flipped classroom implementation, for instance to know whether any activities are missed. Moreover, spontaneity during in-class activity needs to be avoided (Arnold-Garza, 2014). Hence, preparation is very important in flipped classroom model.

Flipped classroom may lead to several problems for both students and instructor who are new to this instruction as pronounced by Herreid and Schiller (2013). Firstly, the students may not be ready for the class because they have not yet watched the video and do the following task. It may be difficult for them to follow the active learning in the classroom. Secondly, it may be difficult for the instructor to find or make a good video for pre-class activity. Technology may be a down pit for several instructors, but it is a demand for instructors to always learn something new and good for their class. In addition, if instructors can well adapt to the innovative and cutting edge technology and able to apply it in their lecture, it will be an interesting and engaging classroom that is beneficial for both students and instructor (Lafee, 2013).

\section{Conducting Flipped Classroom in Writing Class}

To conduct the flipped classroom, a platform to support the online-based material is needed. Edmodo is a learning network which provides teacher to create and manage an online classroom (Kongchan, 2013). After the teachers create the classroom, the teachers can distribute the classroom code to their students. No one else can participate the class unless they are accepted by the teacher.

In Edmodo, teacher can input file, make quizzes, give feedback and assign grades, and many more functions that is similar with what can be done in face-to-face classroom. A study by Kusumaningrum (2018) on effectiveness of Edmodo to perform teacher and peer feedback to improve students' writing ability showed that students' did not perform better than conventional teacher and peer feedback. Some of the reasons are the indirectness of the feedback, poor internet connections and lack of two-way communication. From this study, the researcher will do the feedback on Edmodo yet the students' are able to discuss further with instructor and peers in the class to deepen the understanding.

The pre-class activities included in Edmodo are video lecture and tasks (topic selection and mind map). Using Video lecture is one of the most recommended activities to be used in flipped classroom. Another result from Long, Logan, and Waugh (2016) that students liked the pre-class video lecture because of the new experience and they can take full control about the video. In addition, the students preferred videos from popular video site, such as YouTube and Discovery channel.

Other pre-class activities, alongside with video lecture are tasks. Mind map is to convey the ideas into visual format. The purpose of mapping helps the students to arrange and categorize their idea to comprehend the information and find the relationship between the ideas. Mapping appears as a hierarchical structure started from general concept to specific concepts (Pribadi, 2018). 
As what have been stated before, in-class activity is based on student-centered which stimulates students' active learning. After that, in in-class activity the students will discuss the activity that they have done online with peers and the instructor. Brainstorming the writing draft and have peer feedback or demonstrate on what they have learned. As study by Wardani (2011) investigated on the effect of peer feedback on eighth graders writing ability showed that it successfully improved their writing ability also their activeness in teaching-learning process.

\section{Students' Perceptions toward Flipped Classroom}

After conducting the flipped classroom, to know whether it leaves a good impression for students or not, an evaluation within students' point of view is needed. Efron (1969) states that perception is a form of a relationship between belief as the result thinking process with the surrounded universe. As Rookes and Wilson (2005) say perception is a process covering recognition, awareness, and interpretation that involving the human's senses towards something. Therefore, perception is a form as the result of human' awareness and belief towards something.

There are already many researches on the effect of flipped classroom, yet there is still few researches on the students' perception of flipped classroom, especially flipped classroom on writing class. Due to the students are the one who got the effect of the flipped classroom model, this study is conducted to reveal their perceptions of the flipped classroom model. Henceforth, this study not only focuses on the effectiveness on flipped classroom, but also the students' perception of flipped classroom.

There are several studies on students' perception on flipped classroom. Zainuddin \& Attaran (2016) did a survey, focus group, and interviews on 13 postgraduate students on Research in Education course. The result of this study was the students had positive attitudes toward the flipped classroom. The video provided as pre-class activity was an advantage for the students. They had a full control on the video; they can play, pause, and rewind the video to match their own paces of learning. Moreover, the result also showed that flipped classroom could build a good communication between the students.

Yujing (2015) did a research on Chinese university students who taught by using flipped classroom on English writing course to know their perceptions toward the model. By collecting data through questionnaires, it showed that this model successfully ignite learners' interest in learning due to the freedom of learning pace that is up to the learner.

Another students' perceptions study in writing, Afrilyasanti, Cahyono, and Astuti (2017) conducted a study on Indonesian students' perceptions toward flipped classroom by collecting data using questionnaires, interviews and observations. This study covered two areas, which are meaningfulness and students' writing competence. Both of the areas showed that the flipped classroom was meaningful and gave an improvement to their writing competence. There was a suggestion to not discuss the video as in-class activity whereas the video is served as pre-class activity.

Therefore, from the background of study and the literature review that have been explained before, this present study explained about the students' perceptions on the implementation of flipped classroom model on based on the meaningfulness of writing activities and their writing competence.

\section{METHOD}

This research was aimed at investigating the perceptions of flipped classroom on Indonesian EFL undergraduate students. Before did the survey on the implementation of flipped classroom, flipped classroom method have been implemented to a writing class. The participant was fourth semester undergraduate student, in total 30 students consisted of 12 male students and 18 female students. To find out students' perceptions on flipped classroom, questionnaire on students' perception was applied and distributed. A 
questionnaire developed by Weber, Martin, $\&$ Cayanus (2005) is an 18-item questionnaire of Learner Empowerment Scale (LES). The purpose of this questionnaire is to measure student interest. This questionnaire was used by Yujing (2015) and Afrilyasanti, et al. (2017) to find out students' perceptions about flipped classroom model.

The original version by Weber, et al. (2005) consists of three aspects, which are meaningfulness, impact, and competence. Meaningfulness refers to how significant flipped classroom is to students, thus they will do their best to complete the task in flipped classroom. Impact relates to how each student feels important and makes a difference in the classroom. Lastly, competence is students' self-evaluation toward their abilities in completing the task. Meanwhile Afrilyasanti, et al. (2017) only used two aspects, namely meaningfulness and competence. The total of questions are also slightly different, Weber, Martin, \& Cayanus (2005) proposed 12 questions for meaningfulness and competence aspects (Appendix 5), whereas Afrilyasanti, et al. (2017) adapted into 10 questions for the same aspects.

This study used Afrilyasanti, et al. (2017) version since it already used in Indonesian context and included two aspects, namely meaningfulness and competence. The researcher only chose two aspects because the researcher wanted to look out how influential the flipped classroom towards their writing skills and how beneficial the flipped classroom was. To calculate the data, it processed through Microsoft Excel to find the percentages and the mean score of each statement. After quantitative data were statistically obtained, the descriptive statistics were needed.

\section{RESULTS}

To know the students' perceptions on flipped classroom model, the questionnaire sheet was distributed on the last meeting of flipped classroom model on experimental group in total 30 students. The researcher analyzed students' answers by looking at the chosen number. Number 5 stands for strongly agree, 4 is for agree, 3 is neither agree nor disagree, 2 is disagree and 1 is strongly disagree.

The Results of Students' Perceptions on the Meaningfulness of Flipped Classroom

Started from the aspect of meaningfulness, there are 5 statements. The five statements identified whether flipped classroom activities were helpful and favorable for them in learning writing. The results of this aspect are varied.

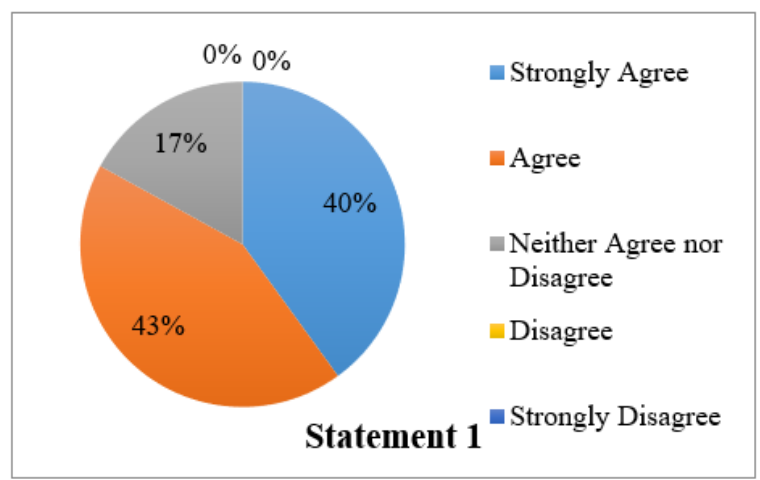

Figure 1. The Result of Statement 1

The first statement, majority of the students agreed $(M=4.23)$, as seen in Figure 1 , that the task and the work to enhance their writing skill are valuable for them or it can be said the flipped classroom's activities had positive response.

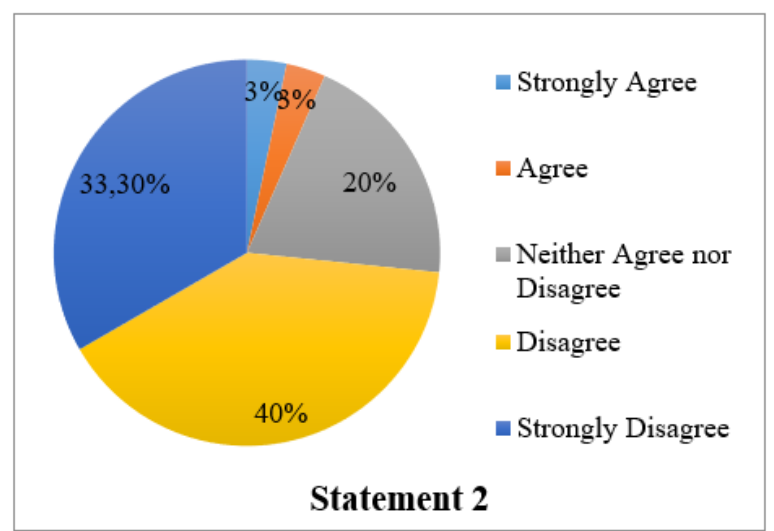

Figure 2. The Result of Statement 2 
The second statement about how the tasks were actually waste of time (Figure 2), majority of the students $(M=2)$ said it was not a waste of time at all. Yet, seven students eventually thought that the tasks were hassle.

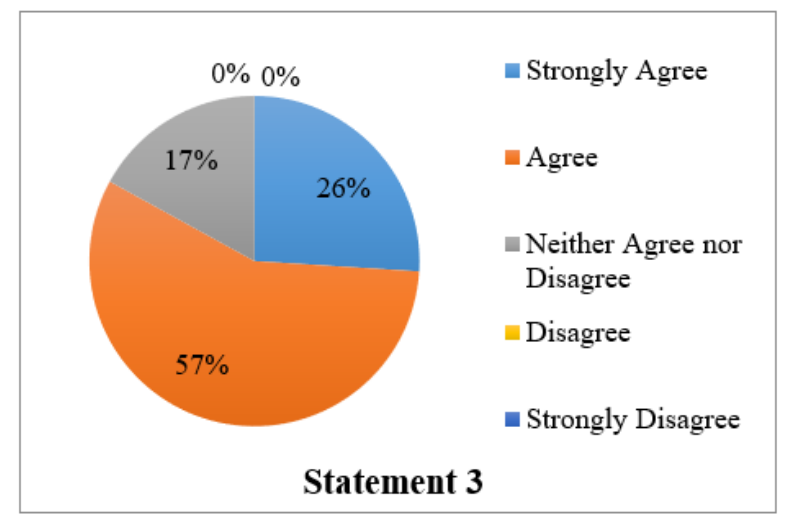

Figure 3. The Result of Statement 3

The third statements (Figure 3), the students agreed $(M=4.1)$ that the activities during flipped classroom improve their understanding of the essay writing key concept. In line with the tasks and activities, the videos and materials that are served as pre-class activities were actually liked by majority of students $(M=3,57)$ to prepare them better before the class, but some of the students had different opinion on it (Figure 4).

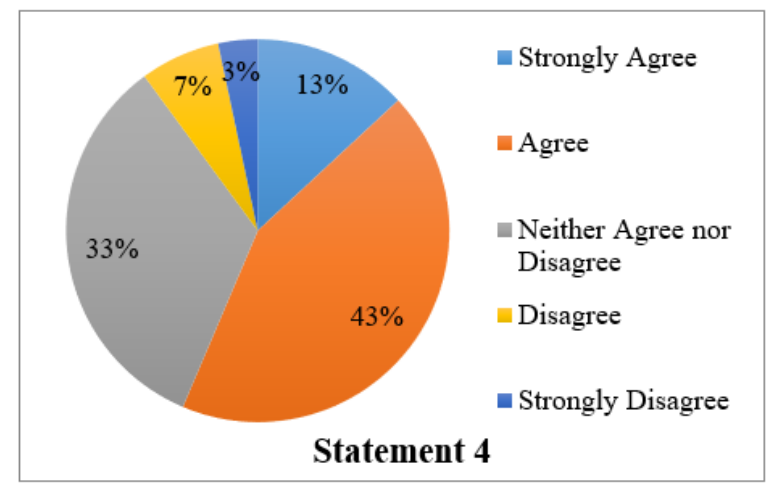

\section{Figure 4. The Result of Statement 4}

This is a challenge for the teacher to think about the other materials that can engage student to learn as pre-class activities. The last statement (Figure 5), about pre-class activity, they did not really see the significance in watching and reading the material before class. The score for this statement is rather neutral; neither disagree nor agree $(\mathrm{M}=2.53)$.

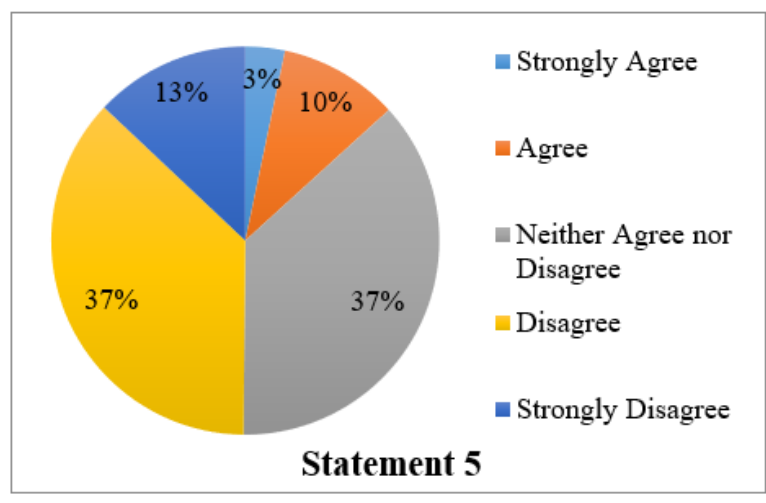

Figure 5. The Result of Statement 5

Thus, the data on meaningful aspect revealed that mostly the students have positive perceptions toward the implementation of flipped classroom. However, for the preclass activities, such as viewing video and reading e-materials, the students had varied perceptions on it. They actually like the idea to have an additional video-lecture and e-material to prepare them before the class, but they did not really see the meaning by doing that pre-class activities.

\section{The Results of Students' Perceptions on the Competence of Flipped Classroom}

The second aspect to find out the students' perceptions toward flipped classroom is the competence aspect. The five statements in competence aspect used to find out their competence in writing as the flipped classroom's outcome.

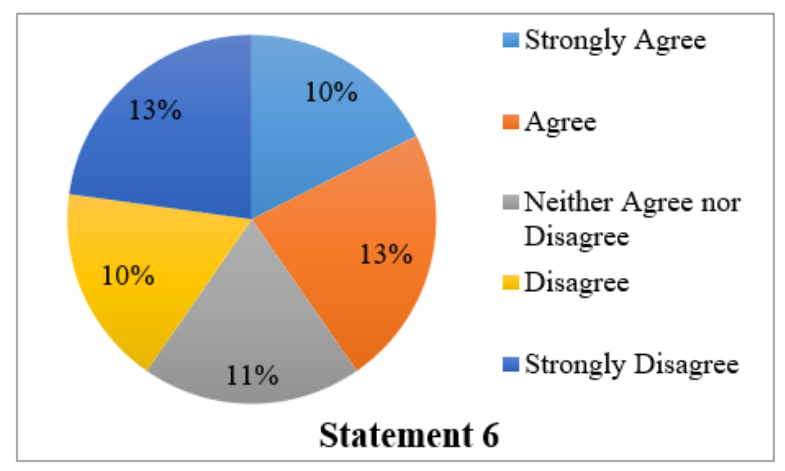

Figure 6. The Result of Statement 6

Regarding to the sixth statement (Figure 6), the students were rather agreed they could do well in writing class $(M=3.5)$. The seventh statement result, as presented in Figure 7, is students were mostly not sure they were 
confident enough to address the topic, as the mean score is leaned to neutral $(M=3.36)$.

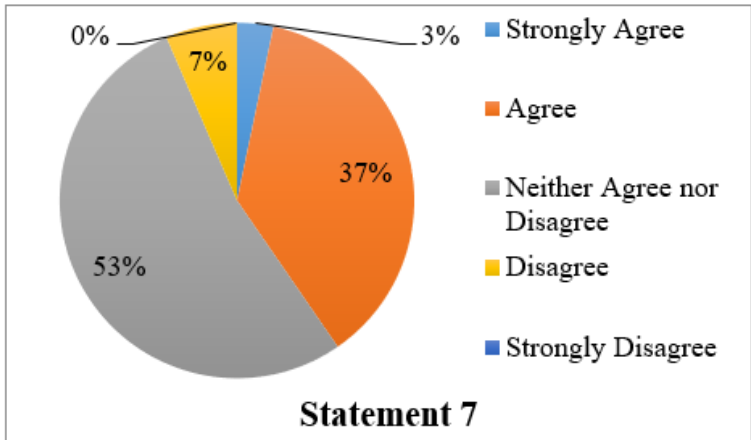

Figure 7. The Result of Statement 7

In the eighth statement about the feedback given as in-class activity, they were agreed $(M=4.2)$ that feedback helps improve their writing (Figure 8).

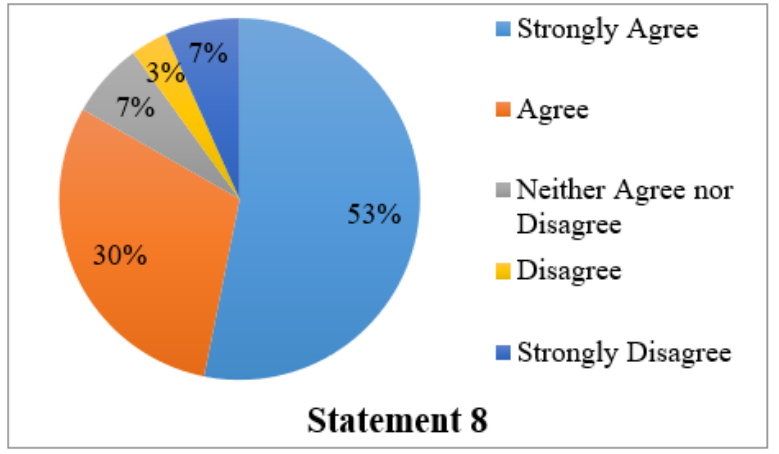

Figure 8. The Result of Statement 8

In the ninth statement, as seen in Figure 9 , the teacher explanation did help them to understand although it was an instant or to the point explanation $(\mathrm{M}=3.9)$.

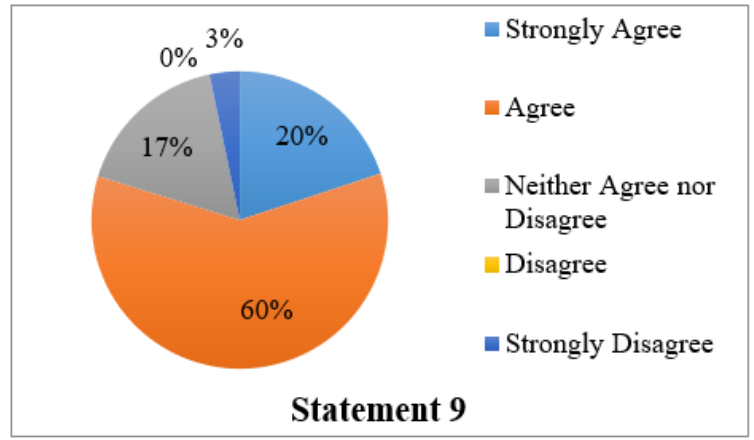

Figure 9. The Result of Statement 9

In the last statement (Figure 10), they agreed that they knew what to do in English writing class $(M=3.8)$. In summary, the students perceived that flipped classroom is beneficial for their writing competence.

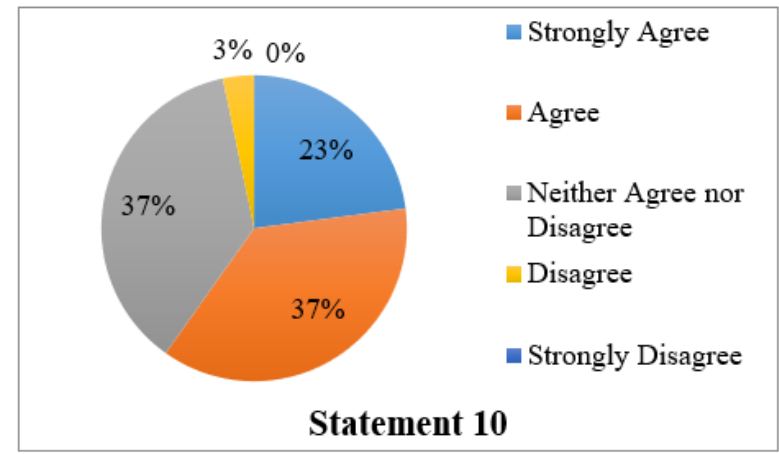

Figure 10. The Result of Statement 10

To sum up, the results between the pre-test and post-test scores and the questionnaire responses are in line. The increasing score of experimental group is supported by students' perceptions of flipped learning, that flipped learning is valuable for their leaning and it has effect on their writing competence. Nevertheless, they perceived that the preclass activities were slightly not beneficial for them.

\section{DISCUSSION}

The results of the questionnaires presented to answer the second research question about students' perceptions on the flipped classroom on how meaningful the learning process and how it effects on their writing competence. By knowing their perceptions, the teacher knows whether they enjoy and feel the advantages of the flipped classroom and also get the clue what needs to be improved or replaced whether the activity or the material.

\section{Students' Perceptions on the Meaningfulness of Flipped Classroom}

The students acknowledged that the activities were really useful for them and they found that the class time which was focused on feedback rather than the material explaining is more valuable. As flipped classroom provides plentiful time to do peer-assisted, collaborative, and cooperative learning between students and teacher, which was really good for them. This result was in line with Bishop \& Verleger (2013). The students were really helped with the peer and teacher feedback to improve their writing.

Meanwhile, using the video-lecture and 
e-material as the primary source of explanation was not really favorable by the students; as the students did not really see the significant of doing that. It can be concluded that they still favor to listen the teacher's explanation in class as primary source and video-lecture and e-material as additional source. The results of this meaningful aspect are in line with the results of Afrilyasanti, et al. (2017), as the students did not really find the value on the pre-class activities.

Altogether, the activities on flipped classroom were worthwhile for the students. Nevertheless for the pre-class activities, the important of doing the pre-class activities were to save the in-class time in order to do more active learning and student-centered. Many students did not find the urgency to do those pre-class activities.

\section{Students' Perceptions on the Merit of Flipped Classroom Model on their Writing Competence}

The students were agreed that the activities on the flipped classroom were meaningful to them. The students perceive that they can address the topic and develop it well. It occurs because flipped classroom employs two stages of learning; pre-class and in-class. Hence, the students felt ready when they entered the classroom, because of the pre-class activities.

The students perceived that peer and teacher feedback help them on their writing. This finding is positively in line with Afrilyasanti, et al. (2017) about the merit of feedback on writing class. By utilizing feedback, the students gained the confidence on their writing since they got their feedback on developed idea, outline, thesis statement, grammar, and all five points of writing rubric. Therefore, they could get better result in the content and context and met the higher score based on the writing rubric.

Another interpretation towards the result of competences aspect is the mean score in each statement tends to be neutral rather than agree. As in the meaningful aspect, the students did not fond of the traditional lecturing was replaced by digital lecturing or video. Although, it was also provided e-material as a supplementary reading in case they found hard to understand the video, still they favor in traditional lecturing. In line with the result of Long, et al. (2016) that flipped classroom was not only about changing the traditional lecture into video lecture. In this study, video might be not sufficient to empower students to understand the material outside the class. Although, the videos were no longer than 20 minutes and there were a following task to prepare them for in-class activities, the students said that they need more than that or more engaging that those activities and materials. Thus, merely depends on video and followed task, it did not make the students had the confidence to write a better essay.

\section{CONCLUSION}

The student perceived that the activities on the flipped classroom were useful and beneficial for them. Moreover, the peer feedback part, it got the most highlighted part of the students. They agreed it enhanced their writing process and result. In another hand, the pre-class activity was supported their understanding but they did not perceive it as a compulsory activity. Instead of becoming the main explanation of the theory, the preclass activities are used as the supplementary activities. Hence, flipped classroom is proven to be beneficial for both parties; students and instructor. Besides, it helps instructor to apply ICT as demand of industrial revolution 4.0. As flipped classroom is already proven as a good method, the next step is to choose and make the suitable materials and platform. In a nutshell, flipped classroom was an effective learning method to enhance Indonesian undergraduate students' writing competence and it is supported by their perception of the implementation of flipped classroom.

\section{REFERENCES}

Afrilyasanti, R., Cahyono, B. Y., \& Astuti, U. P. (2016). Effect of Flipped Classroom Model on Indonesian EFL Students' Writing Ability across and Individual Differences in Learning. International Journal of English Language and Linguistics Research, 4(5), 65-81. 
Afrilyasanti, R., Cahyono, B. Y., \& Astuti, U. P. (2017). Indonesian EFL Students' Perceptions on the Implementation of Flipped Classroom Model. Journal of Language Teaching and Research, 8(3), 476-484. doi: 10.17507/jltr.0803.05

Ahmed, M. A. E. A. S. (2016). The Effect of a Flipping Classroom on Writing Skill in English as a Foreign Language and Students' Attitude towards Flipping. USChina Foreign Language, 14(2), 98-114. doi: http://dx.doi.org/10.17265/15398080/2016.02.003

Arnold -Garza, S. (2014). The Flipped Classroom Teaching Model and its Use for Information Literacy Instruction. Communications in Information Literacy, 8(1), 7-22. doi: $\quad$ http://dx.doi.org/10.15760/ comminfolit.2014.8.1.161

Bishop, J. L., \& Verleger, M. A. (2013). The Flipped Classroom: A Survey of the Research. In Proceedings of 120th ASEE Annual Conference and Exposition. Atlanta, GA (Vol. 30, No. 9, pp. 1-18).

Efron, R. (1969) What is Perception?. In: Cohen R.S., Wartofsky M.W. (Eds.) Proceedings of the Boston Colloquium for the Philosophy of Science 1966/1968. Boston Studies in the Philosophy of Science, vol 4. (pp. 137-173). Dordrecht: Springer.

Gagnon, P., Mendoza, R., \& Carlstedt-Duke, J., (2017). A Technology-Enabled Flipped Classroom Model. In C. Reidsema, L. Kavanagh, R. Hadgraft \& N. Smith (Eds.), The Flipped Classroom: Practice and Practices in Higher Education (pp. 211228). Singapore: Springer Nature.

Herreid, C. F., \& Schiller, N. A. (2013). Case Studied and the Flipped Classroom. Journal of College Science Teaching, 42(5), 62-66.

Hsieh, B. (2017). Step by Step, Slowly I Flip. In L. S. Green, J. R. Banas, \& R. A. Perkins (Eds.), The Flipped College Classroom: Conceptualized and Re-Conceptualized (pp. 11-36). Switzerland: Springer International Publishing.

Ishak, T., Kurniawan, R., \& Zainuddin, Z. (2019). Implementasi Model Pembelajaran
Flipped Classroom Guna Meningkatkan Interaksi Belajar Mahasiswa pada Mata Kuliah Manajement Informasi dan E-Administrasi. Edcomtech, 4(2), 109119.

Kongchan, C. (2013) How Edmodo and Google Docs Can Change Traditional Classrooms. In The European Conference on Language Learning 2013 Official Conference Proceedings. Aichi: The International Academic Forum.

Kusumaningrum, S. R. (2018). The Effect of Teacher and Peer Feedback Provided through Edmodo on Students' Writing Performance. Unpublished disertation, Universitas Negeri Malang, Malang.

Lafee, S. (2013). Flipped Learning. Education Digest, 79(3), 13-18.

Long, T., Logan, J., \& Waugh, M. (2016). Students' Perceptions of the Value of Using Videos as a Pre-class Learning Experience in the Flipped Classroom. TechTrends, 60(3), 245-252. doi: https:// doi.org/10.1007/s11528-016-0045-4

Pribadi, B. A. (2018). Use of the Concept Mapping Strategy to Improve Academic Writing. In K. A. Persichitte, A. Suparman \& M. Spector (Eds.), Educational Technology to Improve Quality and Access on a Global Scale: Papers from the Educational Technology World Conference (ETWC 2016) (pp. 273-285). Cham, Switzerland: Springer Nature.

Reidsema, C., Hadgraft, R., \& Kavanagh, L. (2017). Introduction to the Flipped Classroom. In C. Reidsema, L. Kavanagh, R. Hadgraft \& N. Smith (Eds.), The Flipped Classroom: Practice and Practices in Higher Education (pp. 3-14). Singapore: Springer Nature.

Rookes, P., \& Wilson, J. (2005). Perception: theory, development, and organisation. Philadelphia: Taylor \& Francis e-Library.

Wardani, H. K. (2011). The Use of Peer Feedback to Improve the Writing Ability of the Eighth Graders of MTSN Bangkalan. Unpublished master thesis, Universitas Negeri Malang, Malang.

Weber, K., Martin, M. M., \& Cayanus, J. L. (2005), Student interest: A two-study re-examination of the 
concept. Communication Quarterly, 53(01), 71-86. doi: https://doi. org/10.1080/01463370500055996

Yujing, N.(2015).InfluenceofFlipped Classroom on Learner's Empowerment-A Study Based on English Writing Courses in China. Journal of Literature, Languages and Linguistics, 12(1), 1-7.
Zainuddin, Z., \& Attaran, M. (2016). Malaysian students' perceptions of flipped classroom: a case study. Innovations in Education and Teaching International, 53(6), 660-670. doi: 10.1080/1470329 7.2015 .1102079 